\title{
The Value of Subject Specialization and the Future of Science Liaison Librarianship
}

\author{
Laura Palumbo, Jeffra D. Bussmann, and Barbara Kern
}

\begin{abstract}
Through a survey of more than 200 US academic science librarians, we investigated the perceived value of subject specialization; looked for trends toward or away from science subject specialization; and analyzed predictions about the future of science liaison librarianship. Results showed that science librarians perceive subject specialization positively and predict it will continue to be necessary in the future. They also perceive that liaison relationships will remain crucial. While functional roles appear to be growing, they were not seen as replacing traditional subject responsibilities. Results suggest a shift toward a more generalist approach; however, additional research is needed before stating this conclusively.
\end{abstract}

\section{Introduction}

The topics of subject and liaison librarianship have been studied for a variety of purposes during the last several decades. A remarkably prescient essay from 1970 calls for the "creative subject specialist" to remove himself from service desks and integrate more with faculty. ${ }^{1}$ The related concept of liaison librarianship developed in parallel, often overlapping and intersecting with subject librarianship, with the two concepts being inextricably linked and often interchangeably used. While much has been written about the changing roles of academic librarians and their evolving responsibilities in liaison activities, the question of whether or not science subject expertise will continue to be a necessary component of the liaison relationship has not been adequately addressed.

This question was in part motivated by the authors' observation that recently, academic libraries seem to be under pressure to make do with less. Although not the direct subject of this research, the circa 2008 US recession had an impact on the operations of many academic libraries, including a reduction in collections spending ${ }^{2}$ and library personnel. ${ }^{3}$ As a result, liaison librarians may have broadened their liaison responsibilities to departments in which they have had little subject knowledge, as well as taking on more functional responsibilities. Correspondingly, science librarians may be observing that the perceived value of science expertise has diminished.

The authors sought to gain insight from both science librarians and library administrators (University Librarians, Library Deans, or Directors of Libraries). However, due to the volumi-

Laura Palumbo is Chemistry \& Physics Librarian/Science Data Specialist at Rutgers University; email: laura. palumbo@rutgers.edu. Jeffra D. Bussmann is Associate Librarian at California State University-East Bay; email: jeffra.bussmann@csueastbay.edu. Barbara Kern is Director, Sciences and Social Sciences Libraries at the University of Chicago; email: bkern@uchicago.edu. (2021 Laura Palumbo, Jeffra D. Bussmann, and Barbara Kern AttributionNonCommercial (https://creativecommons.org/licenses/by-nc/4.0/) CC BY-NC. 
nous quantity of data collected, this article focuses on the analysis of data collected only from science librarians. We anticipate publishing a separate article reporting on the results of the survey of library administrators at a future date.

Some essential definitions are needed for understanding this research. The authors provide the following definitions as they relate to this paper.

- Science education is a degree, undergraduate and/or graduate, in a Science, Technology, Engineering, or Mathematics (STEM) field.

- Science experience is previous work experience in a science library, or a scientific or related field.

- Subject specialist is a librarian with specialized knowledge and experience to select materials and provide information literacy instruction and reference services to users in a specific subject area or academic discipline (or subdiscipline).

- Science liaison librarian is a librarian with liaison responsibilities to one or more STEM departments, with subject knowledge in these disciplines.

- Functional responsibilities refer to activities performed by liaison librarians that are outside of the traditional responsibilities of collection development, instruction, and reference. Examples include scholarly communication work, research data management services, and undergraduate student success.

- Generalist is a term used to describe a librarian who covers many subjects and/or subjects that have no established field-closeness; rather than a single or closely related few.

Given these definitions and the information gap in science liaison librarianship, the authors established the following questions:

1. Do science librarians perceive a benefit to having a science education and/or experience in the practice of science liaison librarianship?

2. Do science librarians perceive that subject specialization is necessary for liaison librarianship, or do they believe that liaison librarianship will evolve into a more generalist role?

3. Do science librarians believe that the practice of science liaison librarianship will continue in the future?

Through a survey of more than 200 science librarians in universities and colleges in the United States, this study examines the current state of science liaison librarianship to assess if subject specialization is perceived as valuable by science librarians; to determine if trends toward or away from subject specialization are detected; and to offer some predictions about the future responsibilities of liaison librarians in the sciences. The answers to these questions may be useful to science librarians and library administrators when considering an investment in professional development and staffing needs.

\section{Literature Review}

A literature review revealed that the topic of subject librarianship has been regularly studied throughout the years since the concept of subject specialization was introduced in North America in the mid-20th century. Understanding when this introduction took place depends on the terminology used, which varies throughout the literature. "Subject bibliographer," "subject specialist," and "subject liaison" are the most common terms, and each can include similar or very different responsibilities. Hay traces "subject bibliographers" to before the 1940s and suggests that the need for this expertise was developed to ensure assistance with the 
complex information needs of academic researchers. ${ }^{4}$ Latta states that the concept of "subject specialist" was introduced in North America in the 1960s, ${ }^{5}$ however, Currier uses this same term two decades earlier. ${ }^{6}$ The precise historical development of subject work for academic librarians in the United States is complex. But what is clear is that, while the descriptive term for this work and its precise boundaries have varied over time and place, this subject-focused work has since become a prominent part of the academic librarian workflow.

Emerging and changing roles and an evolving variety of duties for academic librarians are additional repeating themes in the literature. ${ }^{7}$ More specifically, Smith and Oliva discuss the role of reference librarians in providing subject-specific reference support, ${ }^{8}$ while Hazen ${ }^{9}$ as well as Stacy-Bates et al. ${ }^{10}$ discuss the current and future role of subject specialists in collection development responsibilities. The fluctuating nature of the liaison role, including relationships with department faculty and related services, is highlighted throughout the literature. ${ }^{11}$ Other articles provide replicable models for subject specialist services and/or best practices at specific institutions. ${ }^{12}$

Furthermore, several articles have been written about subject specialization specifically within the sciences. The topics range from the educational background of science librarians such as the work by Hallmark, ${ }^{13}$ who focused on the geoscience librarian, to continuing education and skill-building efforts for engineering librarians as discussed by Renfro and Critz. ${ }^{14}$ Chemistry librarians are the focus of Hooper-Lane,${ }^{15}$ who conducted a study to better understand how they gain chemistry knowledge, as well as methods of maintaining this knowledge. Several articles in the literature address the topic of science librarians holding academic degrees in their specific field of specialization, including whether or not this is necessary to be successful as a librarian. ${ }^{16}$ While there are differing opinions, there appears to be a general consensus that, although competence in a subject area is critical, how this competence is obtained can vary.

Whether considering science librarianship specifically, or subject librarianship more broadly, surveys have been a popular tool to better understand the role of the subject specialist liaison in academia. The results of the surveys, published throughout the literature, have come to differing and sometimes conflicting conclusions regarding the central role of the liaison librarian or subject specialist. One such survey was conducted in 1992 by the Association of Research Libraries (ARL) Office of Management Services, with the results published in SPEC Kit 189, Liaison Services in Academic Libraries. After the analysis of survey results from 49 institutions, the authors found that there was not one typical type of liaison position; responding institutions reported an array of titles for liaison librarians, differing audiences for services, and a variety of responsibilities and activities. ${ }^{17}$ More than a decade later, in 2007, ARL published SPEC Kit 301, Liaison Services, in which they examined the role of liaison librarians and pointed to a larger suite of responsibilities. ${ }^{18}$ Then, in 2015, a new ARL SPEC Kit 349 was published on the Evolution of Library Liaisons; this report, along with more recent articles, describe new areas of functional responsibility for liaison librarians. ${ }^{19}$ These areas include scholarly communication, data management, and outreach and are more deeply addressed by Kirchner, ${ }^{20}$ Gabridge, ${ }^{21}$ Peters and Dryden,,${ }^{22}$ and Williams, ${ }^{23}$ respectively. More recently, ARL published Research Library Issues 294 that highlights how five institutions redefined and reorganized their library liaisons and discusses how they have been "striving for a rebalance of activities." 24 These publications demonstrate that subject liaison librarianship in U.S. academic institutions has evolved in noteworthy ways, and whether or not this 
evolution will favor science liaison librarians' continued existence or their extinction will be explored in part through this article.

\section{Methodology}

We sought to answer the research questions through the use of a survey of academic science librarians in the United States. Prior to creating our survey questions, we reviewed published surveys on liaison librarianship broadly and in particular, McAbee and Graham ${ }^{25}$ and Nero and Langley. ${ }^{26}$ From this review, we created a survey instrument using Qualtrics that contained 30 questions that were arranged in three categories: 1) Demographic and subject background information, 11 questions; 2) Institutional information, 9 questions; and 3) Current job responsibilities and future predictions, 10 questions. The question types were multiple-choice, Likert scale and matrix table, short-answer, and free-text response (see the appendix for the survey instrument). The survey was tested by a science librarian with a PhD in Library and Information Science, two PhD social science librarians (one with expertise in quantitative data analysis), and a faculty member in the Statistics department. Per their suggestions, revisions were made to survey questions' types and the order of questions, and additional details were provided for clarification.

The survey of science librarians was distributed to members of the Association of College and Research Libraries Science and Technology Section's email listserv, STS-1, and was open for responses for approximately three weeks in November and December of 2017. To be eligible to complete the survey, list members needed to indicate being employed as a librarian covering a STEM field at an academic library in the United States. Health Science librarians were excluded from the survey if they only served health science departments (medical, nursing, health science, public health, and such); however, librarians who acted as liaisons to health science departments in addition to at least one STEM discipline were eligible to take the survey.

The number of subscribers to the STS-1 email list exceeds 2,000, but almost half of these have email addresses that are not .edu, with about a third having a domain representing a country other than the United States. Because there was no way to clearly identify subscribers to STS-1 who were eligible to take our survey, the membership of the Science and Technology Section (STS) was used as a proxy for the population of U.S. academic science librarians. During November and December of 2017, when the survey was distributed and open for responses, the number of Personal-Regular members of STS was 959 and 953 respectively, so an average population size of 956 was assumed.

There were 248 respondents to the survey, including five who were ineligible to take the survey and were forced to exit. There were 201 eligible respondents who completed the entire survey. If we calculate the maximum response rate as the number of complete responses plus partial responses, divided by the total number in the eligible sample, ${ }^{27}$ the response rate is 25.4 percent. Respondents could select which questions to answer or not; therefore, the rates will vary by question with the number of responses for each question. The response rate for fully completed surveys is 21.0 percent. The number of nearly completed surveys was relatively high: only 13 respondents completed less than half of the survey; 230 completed 66 percent of the survey; and 214 completed 75 percent of the survey.

The majority of the analysis of survey data was performed through Qualtrics using the Reports and Data Analysis tools. Qualtrics used all available data without any listwise deletion. For questions that allowed for open response writing, text analysis was used to draw 
out common themes from individual ideas, words, or phrases that were repeated among the responses. In performing the text analysis, each author individually read and tagged responses for themes, and consensus was reached after comparison and refinement of tags. We also used Qualtrics sentiment analysis tool to determine if the respondent's outlook was generally optimistic, pessimistic, or mixed about the future. Results are shared in five categories: Demographics of Respondents; Respondents' Institutional Demographics; Respondents' Job Responsibilities; Deeper into Science Liaison Work; and finally, Final Thoughts from the Respondents.

\section{Results}

\section{Demographics of Respondents}

Respondents were primarily newer science librarians, with 42 percent having five or fewer years' experience and roughly 18 percent having six to ten years, totaling approximately 60 percent being in their first decade as a science librarian. Around the middle, from 11 to 20 years of experience, there were 20 percent of respondents. Librarians with 21 years or more as an academic science librarian made up 18 percent of the respondents $(n=243)$. Respondents were also asked about their overall length of time as librarians, acknowledging that people have changed careers even within librarianship ( $\mathrm{n}=$ 231). These responses are more distributed than those for years as an academic science librarian. Even so, similar to the responses from the previous question, more respondents identified as newer librarians (50\% having 10 or fewer years) than experienced librarians ( $25 \%$ having 21 years

\begin{tabular}{|l|c|c|}
\hline \multicolumn{3}{|c|}{ TABLE 1 } \\
Years as an Academic Science Librarian \\
and Librarian \\
\hline & \multicolumn{2}{|c|}{ Number of Respondents } \\
\hline Years as a(n): & $\begin{array}{c}\text { Academic } \\
\text { Science Librarian }\end{array}$ & Librarian \\
\hline $0-5$ yrs & 102 & 73 \\
\hline $6-10$ yrs & 43 & 41 \\
\hline $11-15$ yrs & 33 & 39 \\
\hline $16-20$ yrs & 16 & 21 \\
\hline $21-25$ yrs & 13 & 20 \\
\hline$>25$ yrs & 31 & 37 \\
\hline & $\mathrm{n}=238^{*}$ & $\mathrm{n}=231$ \\
\hline
\end{tabular}

*Does not include the 5 respondents who indicated they were not an academic science librarian or more). (See table 1.)

Position titles provide additional insight into how science librarians view themselves. This survey question was an open-text field, where 163 respondents entered their titles. There was a notable variety in the titles provided, so the authors created codes for repeating position title themes, in which a respondent's position title may have received more than one code. Perhaps not surprisingly, the greatest quantity (69 respondents, $42.3 \%$ ) of responses were a near title match to that of Science Librarian, STEM Librarian, or Science \& Engineering Librarian. More narrowly, some respondents' titles expressed particular science specialties (38 respondents, 23.3\%), such as Environmental Science Librarian or Chemistry Librarian. Other titles were based more on function or the kind of librarian work they do (60 respondents, $36.8 \%$ ), such as Reference and Instruction Librarian, Data Management Librarian, or Head of Branch Library. Several were rank-based titles, such as Assistant Librarian, Science Library Director, or Assistant Professor (23 respondents, 14.1\%).

Academic science librarians may also have a degree in a science discipline because this is often listed as at least a "desired" quality (if not required) in position descriptions of job announcements. ${ }^{28}$ Of the 218 respondents who answered this question about degrees held (see table 2), biology and life sciences had the most science degrees (75) earned among the 
respondents, followed at a distance by chemistry and biochemistry with the second-most degrees (25). There were 79 respondents to this question who had bachelor's degrees in nonscience areas. Respondents could have selected multiple degrees (bachelor, master, and/or doctorate) in one disciplinary field or over multiple disciplinary fields. Written in the "Other science degree" options included many that were bio-related (such as molecular biology, zoology, microbiology, plant sciences, bioinformatics) as well as more specific fields such as anthropology, pharmacy, and geography. All but one respondent had earned a Master in Library and Information Science or ALA-accredited equivalent degree.

\begin{tabular}{|l|c|c|c|c|}
\hline \multicolumn{5}{|c|}{ TABLE 2 } \\
\hline Respondents' Science Liaison Areas and Science Degrees \\
\hline Science Subject & Liaison Assignment & BA/BS & MA/MS & Doctorate \\
\hline Agriculture & 34 & 6 & 5 & 2 \\
\hline Astronomy & 64 & 1 & 2 & 1 \\
\hline Biology/Life Sciences & 118 & 59 & 14 & 2 \\
\hline Chemistry/Biochemistry & 119 & 19 & 5 & 1 \\
\hline Computer Science & 73 & 2 & 2 & 0 \\
\hline Earth Sciences/Geology & 78 & 10 & 3 & 4 \\
\hline Environmental Sciences & 90 & 8 & 2 & 0 \\
\hline Engineering & 83 & 8 & 3 & 1 \\
\hline Food Science/Nutrition & 23 & 1 & 0 & 0 \\
\hline Health Sciences & 35 & 2 & 1 & 1 \\
\hline Marine Science & 24 & 0 & 0 & 0 \\
\hline Mathematics & 90 & 7 & 1 & 0 \\
\hline Medicine & 11 & 0 & 0 & 0 \\
\hline Neuroscience & 29 & 2 & 0 & 0 \\
\hline Nursing & 24 & 1 & 0 & 0 \\
\hline Physics & 107 & 10 & 2 & 1 \\
\hline Psychology & 17 & 0 & 2 & 0 \\
\hline Statistics & 43 & 92 & 48 & 0 \\
\hline Other \& Non-Science & 74 & & & 5 \\
\hline
\end{tabular}

Respondents were also asked what subject experience or education they had when they began their current position, and they could select more than one answer (see table 3 ). Having a science or subject-related degree, experience within a library setting, or experience outside

\section{TABLE 3}

\section{Respondents' Previous Science Background}

\begin{tabular}{|l|c|c|}
\hline Respondents' Previous Science Background $(\mathrm{n}=231)$ & Count & Percent \\
\hline Science or subject related degree(s) & 144 & $62.3 \%$ \\
\hline Science or subject related experience outside of libraries & 127 & $55.0 \%$ \\
\hline Library experience in subject area(s) & 138 & $59.7 \%$ \\
\hline No science or subject related degree or experience & 23 & $10.0 \%$ \\
\hline Note: Respondents could select more than one option. & \multicolumn{2}{|l}{} \\
\hline
\end{tabular}


a library position were selected fairly evenly $(62.3 \%, 59.7 \%, 55.0 \%$, respectively). Very few $(10 \%)$ of the respondents were without either a science/subject-related degree or experience $(\mathrm{n}=231)$.

\section{Respondents' Institutional Demographics}

The next set of questions inquired after the characteristics of the respondents' institutions and libraries. Because respondents could be employed at the same institution but did not report the name of their institution, there may be overlap in the institutional data. Thus, these results are merely descriptive of our respondents, academic science librarians, rather than of distinct U.S. academic institutions. In addition, respondents were not required to answer all questions, causing the number of responses to vary from question to question. The vast majority $(83 \%)$ of the respondents $(n=227)$ represented institutions that offer doctorates as the highest attainable degree, while significantly fewer offered master's (11\%) and bachelor's $(6 \%)$ as their highest degrees. However, it is not clear if these doctorates are being given in science-related fields. One third of the respondents work at colleges and universities that have 30,000 or more students. Around 40 percent of the respondents are distributed evenly between 10,000-19,999 and 20,000-29,999 student-populated institutions. Respondents from less than 3,000 were the least represented group (under 10\%). A little more than two-thirds of the respondents were from public institutions, while the remaining third were from private institutions $(n=225)$.

Respondents were asked to share how many science librarians their institution employs $(n=225$, see table 4$)$. More than a third of the respondents work with one to three other science librarian colleagues $(84,37.3 \%)$, a little more than a quarter of respondents $(59,26.2 \%)$ work as

\begin{tabular}{|l|c|c|}
\hline \multicolumn{3}{|c|}{ TABLE $\mathbf{4}$} \\
Respondents Working at Institutions with Science Libraries and Science Librarians \\
\hline At your institution... & Count & $\%$ \\
\hline ... how many dedicated science libraries are there? (n=226) & 89 & $39.4 \%$ \\
\hline None & 55 & $24.3 \%$ \\
\hline 1 Science Library & 27 & $11.95 \%$ \\
\hline 2 Science Libraries & 15 & $6.6 \%$ \\
\hline 3 Science Libraries & 8 & $3.5 \%$ \\
\hline 4 Science Libraries & 8 & $3.5 \%$ \\
\hline 5 Science Libraries & 7 & $3.1 \%$ \\
\hline 6 Science Libraries & 17 & $7.5 \%$ \\
\hline 7 or more & Count & $\%$ \\
\hline .. how many science liaison librarians are there? (n=225) & 1 & $0.4 \%$ \\
\hline None & 59 & $26.2 \%$ \\
\hline 1 Science Librarian & 84 & $37.3 \%$ \\
\hline 2-4 Science Librarians & 51 & $22.7 \%$ \\
\hline 5-7 Science Librarians & 14 & $6.2 \%$ \\
\hline 8-10 Science Librarians & 12 & $5.3 \%$ \\
\hline 11-13 Science Librarians & 4 & $1.8 \%$ \\
\hline 14 or more & & \\
\hline
\end{tabular}


the only science librarians at their institutions, and a little less than a quarter work with four to six other science librarian colleagues (51, 22.6\%). A smaller set $(16,7.1 \%)$ of respondents have 10 or more science librarian colleagues at their institution. Respondents were also asked if the number of science librarians at their institution had increased or decreased in the time that they have worked there. More than half of them (124 respondents) indicated the number had stayed the same. A quarter of the respondents (56) noted that the number of science librarians had decreased, while the remaining 18 percent said the number had increased.

\section{Respondents' Job Responsibilities}

Respondents were asked to select the science-related subjects for which they provide library and information services from a multiple choice list $(n=231$, see table 2$)$. Biology/life sciences, chemistry/biochemistry, and physics were the top subjects covered by the respondents (over 100 for each, ranging $46 \%-51 \%$ of the respondents). Environmental sciences, engineering, and mathematics were the next group of liaison subject areas by the respondents. In the "Other" category, where respondents could write in liaison subject areas that were not present in the multiple choice options, answers varied from aviation science, exercise science, forensic science, and industrial technology, to agribusiness economics, human capital development, social work, and urban planning. It is important to acknowledge that colleges and universities offer some very specialized degrees, and libraries and librarians must be familiar with them to meet the information needs of the faculty and students in these departments.

A librarian's subject liaison responsibilities can change over time. Respondents $(n=231)$ were asked if they had assumed new liaison responsibilities in the last five years (approx. 2012-2017). Nearly half of the respondents indicated they had taken on new liaison departments. As a follow-up question, those respondents who had assumed additional liaison responsibilities were also asked if the new departments were science, nonscience, or both (n $=106)$. The majority $(70 \%)$ only added science subjects, but more than a quarter $(29 \%)$ of the respondents added a nonscience subject to their liaison duties. To ascertain the reason for the additional subject coverage, respondents were asked to select from a multiple-choice selection of potential reasons. Most respondents selected a reduction in the number of librarians due to retirement or the departure of a librarian for a new position elsewhere (nearly equal between the two options). A temporary/interim assignment or new department or research area at the institution were nearly equally selected. In the "Other" option, respondents wrote in a variety of answers, including redistribution due to a new hire, redistribution due to preferences, reorganization of the library, and reorganization of the subject departments.

Beyond the subject liaison work noted in the literature review, academic librarians sometimes have specific functional responsibilities. Respondents $(n=196)$ were asked to select functional responsibilities they have in addition to those as a science liaison. Most frequently chosen by the respondents was "Instruction/Instructional Design Librarian" with 87 respondents (44.4\%). Scholarly Communication/Open Access and Data Management Services were also frequently selected (about a quarter each). Seventy-seven respondents filled in the "Other" category with additional responsibilities not listed in the options (39.3\%). Frequently identified responsibilities were management/administrative, reference, collection development, and outreach. Some more unique ones included GIS services, RefWorks coordinator, systematic reviews, assessment, research metrics, and grant writing. A few respondents used this space to say that they do not have additional functional responsibilities. 
Deeper into Science Liaison Work

Any portion of the work that an academic science librarian does may not be related to their liaison science subjects, but rather to more generalist librarian work. Respondents ( $n=203-208$; number varied due to optional response requirement) shared the percentage of their time spent on particular librarian activities related to science subject work (see figure 1). Collection development and outreach to departments were on average the top activities, each being around half of the librarians' task time spent on science-related work (52\% and $51 \%$, respectively). The next heavily science-related work areas by average were instruction/information literacy and reference with 43 percent and 32 percent, respectively. Outreach to other campus units or community groups, scholarly communication, and research data management services were all on average around a quarter of the librarians' task time that was considered to be science-related work. Outside service to the professional organizations and research/writing for publication were on average about one fifth of the librarians' task time.

In comparison, the immediately following survey question asked respondents $(n=206-$ 208) to predict the future trend of this percentage of time spent on the same activities related

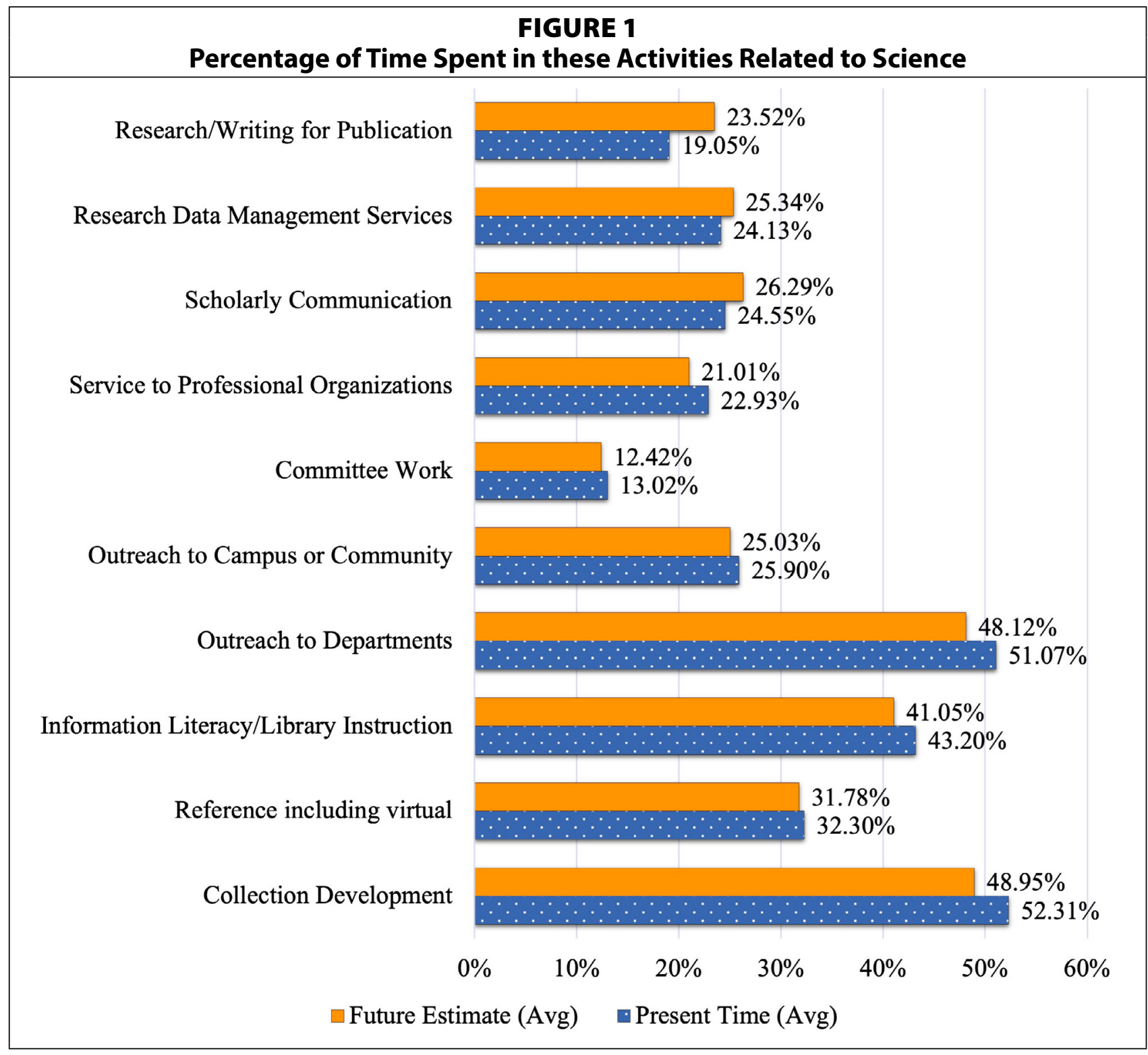


to science. A majority of the activities on average slightly decreased in time spent related to science; however, outreach to campus units and community groups, scholarly communication, research data management services, and research/writing for publication were all predicted to increase on average in percentage of time spent on science-related work (see figure 1).

Respondents ( $\mathrm{n}=197-201)$ were asked to rate the necessity of science subject knowledge in completing various activities of their librarian work, using a Likert scale ranging from 1 being "No subject knowledge is needed" to 5 being "Subject knowledge is essential." The core areas of librarianship, collection development, reference, and instruction were all rated on average between 3 "Some subject knowledge is needed," and 4 "Subject knowledge is important." Outreach to departments, functional expertise (represented by data management services and scholarly communication), and research and writing were rated similarly. While no options received an average rating equal to or above 4 "Subject knowledge is important," no options received an average rating lower than 2 "Subject knowledge is helpful but not essential" (see table 5).

\begin{tabular}{|c|c|c|}
\hline \multicolumn{3}{|c|}{$\begin{array}{c}\text { TABLE 5 } \\
\text { The Necessity of Science Subject Knowledge }\end{array}$} \\
\hline $\begin{array}{l}\text { Activity \& Science Knowledge } \\
\text { (1: Not Needed to 5: Essential, NA = Not Applicable) }\end{array}$ & Avg Rating & NA Count \\
\hline Collection Development $(n=201)$ & 3.53 & 5 \\
\hline Reference incl. virtual $(n=201)$ & 3.49 & 1 \\
\hline Information Literacy/Library Instruction $(n=201)$ & 3.31 & 2 \\
\hline Outreach to Liaison Departments $(n=201)$ & 3.37 & 0 \\
\hline Outreach to other Campus units or community groups $(n=201)$ & 2.53 & 14 \\
\hline Committee Work $(n=200)$ & 2.15 & 18 \\
\hline Service to Professional Organizations $(n=199)$ & 2.29 & 20 \\
\hline Scholarly Communication $(n=199)$ & 3.05 & 25 \\
\hline Research Data Management Services $(n=197)$ & 3.5 & 38 \\
\hline Research/writing for publication $(n=199)$ & 3.2 & 36 \\
\hline
\end{tabular}

Furthermore, respondents $(n=197-200)$ were asked to indicate which of these same activities do they predict will increase, decrease, or stay the same in the future. Overall, very few activities were predicted by the respondents to decrease. Collection development and reference obtained the greatest selection of a predicted decrease $(85 / 42.5 \%$ and $59 / 29.5 \%$, respectively); however, a greater number of respondents indicated that these activities will stay the same $(92 / 46 \%$ and $100 / 50 \%$, respectively). Where the most respondents predicted an increase in workload was research data management services (130/65.7\%), information literacy/instruction (109/54.4\%), scholarly communication (104/52.5\%), and outreach to liaison departments $(100 / 50 \%)$. The activities labeled as committee work (148/74.4\%), service to professional organizations (147/73.9\%), and research/writing for publication (128/65\%) were more greatly predicted to stay the same.

In addition to science librarians' perceptions of a science background (education and/or experience), we asked a question regarding how they perceived others in the library and on campus valuing this specialized background. Science faculty were perceived by respondents $(n=202)$ as most highly valuing the science background in science librarians, followed closely 


\begin{tabular}{|l|c|c|}
\hline \multicolumn{2}{|c|}{ TABLE 6 } \\
\hline \multicolumn{2}{|c|}{ Perceived Value of Science Degree to Job Responsibilities } \\
\hline $\begin{array}{l}\text { Do you think that a science degree, or previous experience in or related to } \\
\text { your subject areas, contributes to your ability to perform your subject job } \\
\text { responsibilities? (n=200) }\end{array}$ & Count & $\begin{array}{c}\% \text { of } \\
\text { Respondents }\end{array}$ \\
\hline $\begin{array}{l}\text { "I don't have a science degree or previous experience, but I think having one or } \\
\text { both would help me perform my subject job responsibilities." }\end{array}$ & 22 & $11.0 \%$ \\
\hline $\begin{array}{l}\text { "I don't have a science degree or previous experience, and I don't think having } \\
\text { either one would help me perform my subject job responsibilities." }\end{array}$ & 7 & $3.5 \%$ \\
\hline $\begin{array}{l}\text { "My science degree or previous experience contributes significantly to my ability } \\
\text { to perform my subject job responsibilities." }\end{array}$ & 107 & $53.5 \%$ \\
\hline $\begin{array}{l}\text { "My science degree or previous experience contributes somewhat to my ability } \\
\text { to perform my subject job responsibilities." }\end{array}$ & 60 & $30.0 \%$ \\
\hline $\begin{array}{l}\text { "My science degree or previous experience does not significantly contribute to } \\
\text { my ability to perform my subject job responsibilities." }\end{array}$ & 4 & $2.0 \%$ \\
\hline
\end{tabular}

by science librarian colleagues. The library administration was most perceived $(20 \%)$ to have a negative value of the science background. Nonscience faculty and students and then librarians follow closely behind with 17 percent and 16 percent, respectively. Only 4 percent of the respondents had a perception of low value by science faculty and their science librarian colleagues.

Survey respondents $(n=200)$ were asked if they thought that their science education or experience contributed to their ability to perform their subject-related responsibilities. More than half of the respondents $(107 / 53.5 \%)$ indicated that their science background has significantly contributed to their performance. A little less than one-third (60/30\%) believed it had somewhat contributed to their performance. Around one-fifth $(22 / 11 \%)$ selected that, while they did not possess a science degree or previous science experience, they thought that one or both would have helped them perform their subject responsibilities. Only 11 respondents (5\%) did not think that the science background contributed to or helped them perform their subject responsibilities (see table 6).

Thinking more about the future of science librarianship and necessity or desirability to have a science background (education or experience), respondents $(n=231)$ were asked to

\section{TABLE 7}

Predictions about the Future of Science Liaison Librarianship

Thinking about the future...

... do you think it will be necessary or desirable for academic science librarians

to have a degree or related experience in a science discipline? $(\mathbf{n = 2 0 0 )}$

A science degree or experience will be necessary

A science degree or experience will be desirable but not necessary

A science degree or experience won't be necessary

... do you think the practice of liaison librarianship in the sciences will continue? ( $n=200)$

Science librarians will continue to liaise with science departments

Most librarians will liaise with both science and non-science departments

Liaison librarianship as a practice will be discontinued

\begin{tabular}{|c|c|}
\hline Count & $\%$ \\
\hline 68 & $34.0 \%$ \\
\hline 127 & $63.5 \%$ \\
\hline 5 & $2.5 \%$ \\
\hline Count & $\%$ \\
\hline 125 & $62.5 \%$ \\
\hline 66 & $33.0 \%$ \\
\hline 9 & $4.5 \%$ \\
\hline
\end{tabular}


share their opinion. Nearly two-thirds of the respondents (126/63.5\%) believed that having a science degree or experience will be desirable but not necessary. One-third (68/34\%) thought a science background would be necessary. Only five respondents out of 231 did not think either a science degree or experience would be necessary in the future.

The final multiple-choice question asked respondents $(n=200)$ to consider the future of liaison librarianship and whether or not it might continue. A majority (125/62\%) believed science liaison librarianship will continue to exist where librarians liaise with specific science departments (see table 7).

\section{Final Thoughts from the Respondents}

One of the last questions of the survey asked respondents to share their thoughts on the future of science librarianship. This was an open-ended question with space for respondents to write more expansively. The authors read through the 139 responses multiple times, created codes (identified with italics below) to represent repetitive themes in the responses, and then tagged the responses accordingly. From this coding, a majority of the responses (86) included comments containing a positive outlook on science librarianship future, current, or past situation. And yet, there was a significant number of responses (51) that included a negative sentiment or concern. Overlapping between these two groups of respondents are those (27) who made comments that were mixed, representing both positive and negative.

Within the topical content of the responses, a large group (50) of respondents discussed functional expertise. One respondent commented, "More functional roles will increase overall though especially with the growing movement in Open Science/Open Scholarship." While less frequently than functional expertise, science expertise (education, experience, or lack thereof) and the core expertise of reference, instruction, and collection development were still mentioned with relative frequency (38 and 34, respectively). One respondent perceived a lesser role for science specialization in the future, stating, "The value of science expertise is likely being diluted due to reductions in numbers of librarian positions..." and yet another contended that science liaison librarianship would persist: "the traditional model of a subject librarian - assigning a librarian to a department to liaise, do collection development, instruction, reference for that department, etc. - will continue to be used in many departments."

If there is any opportunity for growth or improvement, librarians are likely to offer a recommended action (42) that could be taken by themselves, libraries, or administrators. Comments in this vein include, "We do have to make ourselves more useful," "I think it's more important than ever for ALL librarians to get a crash course in science research...," and, "Science liaison librarians have opportunities to adapt and adopt stronger roles..." Recognizing the integral role that patrons play in liaison librarianship was highlighted by many of the respondents (faculty/researchers: 34 and students: 27); such as, "We can bring expertise that our science faculty simply don't have time for, assisting them and their students." Notably, respondents (25) acknowledged that there is institutional influence in the effectiveness of science librarian work: what is successful at one institution may not be elsewhere. Thinking of the future, it is not surprising that terms like change and evolve are used frequently by respondents (54), especially in a time when librarians are operating in "an increasingly complex information environment." Likewise, the perceived value (18) of science librarian work can determine whether or not it continues (25), such as one respondent stated, "we need to continue to prove our value to the communities we serve." 


\section{Discussion}

The responses collected indicate that science librarians generally perceive that the liaison relationship with departments is a valuable and necessary component of academic science librarianship, and that subject specialization benefits this relationship. Many respondents believe that newer functional roles, such as scholarly communication and research data management, will continue to grow and will become more important in the future, but that liaison relationships will remain necessary for these services to succeed. Our results suggest, albeit inconclusively, that there may be a trend toward a more generalist approach to liaison librarianship, with science librarians acting as liaisons to multiple departments and subject areas. The following discussion will address these topics through each of our three research questions, separately.

\section{Do science librarians perceive a benefit to having a science education and/or experience in the practice of science liaison librarianship?}

We found that the majority of survey respondents have a science degree or previous science experience and therefore will have firsthand knowledge of how a degree or previous experience benefits them or does not. However, these science librarians may also be predisposed to valuing this science-focused background more as it relates to their work. The Qualtrics chi square analysis showed that the value of a science degree or experience was independent of whether or not the respondent had one or both, but, due to low expected frequency, the chi square results may not be reliable. Within the limitations of our survey results, the data support the conclusion that science librarians generally perceive a science degree or previous experience in a science-related position to be of value in the performance of their work.

In the responses to open-ended survey questions, some believed that there is a trend toward more, not less, specialization that would require increased demand for science expertise, pointing to areas such as informatics, scholarly communication, and data management. Several expressed the belief that a science background is viewed more favorably by faculty than other disciplinary backgrounds and that science intimidates some librarians. One respondent stated,

Liaison librarianship in the sciences will continue to be necessary because the majority of academic librarians, who don't have a science background, are uncomfortable doing reference and instruction with science departments. The terminology and concepts are ones not easily understood without a science degree, and some understanding is needed to do effective researching and teaching. In addition, librarians with a science background are needed in the areas of scholarly communication and data management to address the unique challenges presented by science data and communication.

A few extended this perception by stating that an advanced degree in a science discipline, without a library degree or experience, was viewed as more valuable than a library degree. One respondent predicted, "There will be more science librarians with advanced degrees in STEM subjects, but without library degrees." However, countering this opinion, another respondent expressed the opinion that, even without a science degree or experience, science subject knowledge is something that can be learned by librarians with dedicated effort over time. 
The data indicate that science librarians think that subject knowledge is most valued by the science faculty with whom they liaise, and least by their library administration. Several of the comments in the open-ended responses support this perceived value, some with rather strong sentiments that communication with faculty would be severely hindered without subject knowledge on the part of the librarian. Negative comments about perceptions of library administration could be indicative of other unspecified issues, and thus, not necessarily related to the perception of the value of a science background by library administration. We hope to uncover more about the values of library administration when the results of our other survey are analyzed.

\section{Do science librarians perceive that subject specialization is necessary for science liaison librarianship, or do science librarians believe that liaison librarianship will evolve into a more generalist role?}

The use of the more generic science titles reported by respondents could indicate a trend away from subject specialization or that librarians are covering multiple subject areas within the sciences. The presence of functional titles, either as stand-alone titles or in combination with liaison roles, possibly signifies increasing importance being placed on functional skills over science subject expertise. One respondent noted that their library was being reorganized toward more functional roles and away from disciplinary roles; however, more research is needed to state conclusively that this is a trend.

In addition to their titles, science librarians reported on their job responsibilities, both related and unrelated to subject areas, and also made predictions about job responsibilities in the future. For traditional activities, such as collection development, instruction, and reference, as well as newer functional ones, such as data management, science subject knowledge was perceived as being a necessary or important requirement. In consideration of data from multiple questions, we can infer that our respondents believe science subject knowledge is needed for the completion of core job responsibilities in the present and will continue to be necessary as newer functional responsibilities grow in the future.

A few respondents to the open-ended question about the future of science librarianship indicated that they thought academic librarians would be moving away from subject specialization and toward more generalist roles. However, some thought that the addition of multiple liaison departments would hurt the librarian's ability to perform their job responsibilities. One respondent claimed that the "push toward generalist roles is administratively driven, and not based on user wants or needs."

Overall, it seems that science librarians perceive a shift away from focused subject specialization but are not sure that this will benefit academic faculty and students. Most believe that liaison relationships will be necessary to continue to do academic librarians' work and that it may in fact be more important for newer functional roles.

\section{Do science librarians believe that the practice of science liaison librarianship will con-} tinue in the future?

When asked whether they thought science liaison librarianship would continue, the majority thought that it would; however, about a third believed that academic librarians would liaise with both science and nonscience departments in the future. The free-text responses confirm that most librarians believe liaison librarianship will continue in the future and that science 
subject knowledge will be a necessary part of the job. Some perceived that liaison roles were transitioning to more purely functional roles, while others believed that most future science librarian jobs would have a combination of functional and liaison roles. One respondent expressed this view of the perceived trend by stating,

The writing is on the wall, library reorganization along strategic planning is realigning positions away from subject/faculty areas to new areas to fall in line with university plans to include areas similar to student success, research lifecycle, reimagining the library experience, engaging our communities and strengthening our capacity. This is tragic as we will lose connections to faculty and researchers in many subject areas where science expertise is essential. I can't think how someone will teach chemistry, business, physics, music, etc. without an academic background in these areas? We will lack our credibility to know science culture, language, ways of communicating and how research is conducted without these backgrounds and credentials.

It was also noted by respondents that newer functional responsibilities, such as data management and scholarly communication, can increase the need for liaison relationships; as one respondent stated, "The functional specialists all depend on our departmental connections to do their jobs."

As with any research undertaking, this study is subject to some limitations, which we would like to acknowledge here. These include the possibility of nonresponse bias, as well as bias on the part of the respondents, the majority of whom had science degrees. For these reasons, we cannot assume that our sample population, while of adequate size, is representative of the population of academic science librarians in the United States. In addition, although we attempted to remain objective, the authors all have science degrees, previous science-related experience, or both. Additionally, the authors have experiential bias relating to their professional experiences as current science librarians of practice. Bias also may be introduced by the respondents being predominantly from large, doctorate-granting institutions, which could have influenced perspectives regarding job responsibilities and the relative importance of science subject specialization. Finally, it should be noted that the data gathered record the perceptions of the subjects, as well as subjective predictions, and these lack more specific evidence for the claims being made.

\section{Conclusion}

We conclude that science librarians perceive that subject expertise, whether gained through a degree or experience over time, is valuable in the performance of their job responsibilities and activities. Science librarians recognize subject expertise as being beneficial in the execution of traditional services, such as collection development and reference, and in newer ones like research data management and informatics, as research becomes more dependent upon computing in data collection and reuse.

The results from our survey point to responsibilities within science librarianship that extend to multiple science departments and, to a lesser degree, to nonscience departments. This may indicate a shift toward a more generalist approach and away from subject specialization; however, additional research is needed to state this definitively. Our research predefined 
science liaison librarianship as combining both subject expertise and a liaison relationship in specific STEM disciplines, but these also may be viewed as separate facets of academic science librarianship. Our results suggest that, in addition to subject specialization, science librarians also perceive the liaison relationship as being a crucial part of science librarians' jobs. The distinction between the two may become more relevant if, in the future, science librarians broaden their liaison responsibilities to multiple subject areas with which they are unfamiliar. A liaison's communication with science faculty and students is critical for meeting their teaching, learning, and research needs; and there was the perception by a few that the ability to communicate effectively would be hindered if a liaison did not also have some subject expertise.

On the whole, science librarians were optimistic that science liaison librarianship would continue in the future. Our research indicates that functional roles are gaining importance; however, the belief that they would someday displace subject specialization was not widely expressed. Newer services like research data management and scholarly communication are perceived by science librarians as requiring both science expertise and liaison connections. And, while not a new role, instruction also seems to be a growing part of science librarian job responsibilities, and the question remains whether the differing disciplinary needs of science departments require some amount of subject expertise with regard to information literacy. Future decisions regarding the development of new roles for academic science librarians may want to consider the importance of liaison relationships, including whether subject specialization should be tied to this role.

Further research is needed to determine if science librarians' job responsibilities are growing to include more liaison departments and functional roles and whether this weakens the ability of science librarians to do their jobs effectively, or if there is a counteracting decrease in demand for library services that allows science librarians to focus more attention on other activities such as new subject areas, scholarly communication, data management, and instruction.

\section{Acknowledgments}

The authors would like to thank Stella Ota and Debra Kolah for their insights into this research. 


\section{APPENDIX. Science Librarians Survey}

\section{Q2 Definitions}

Liaison Librarian: a librarian who is assigned one or more academic departments for which they serve as an intermediary between the library and the faculty and students of that department.

Subject Specialist: a librarian with specialized knowledge and experience to select materials and provide information literacy instruction and reference services to users in a specific subject area or academic discipline (or subdiscipline). Adapted from Online Library for Library and Information Science (www.abc-clio.com/ODLIS/odlis_about.aspx).

For this survey, a science liaison librarian is a librarian with liaison responsibilities to one or more science departments, with subject knowledge in these disciplines.

Q3 How long have you been an academic science librarian?

$\square \quad$ I'm not an academic science librarian (1)

$\square \quad 0-5$ years $(2)$

$\square \quad 6-10$ years (3)

$\square \quad 11-15$ years $(4)$

$\square \quad 16-20$ years (5)

$\square \quad 21-25$ years (6)

$\square>25$ years $(7)$

Skip to: End of Survey if How long have you been an academic science librarian? = I'm not an academic science librarian

Q4 How long have you been a librarian?

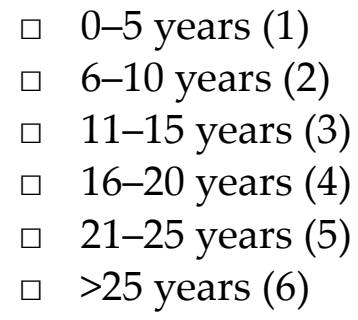

Q5 What is your position title(s)?

Q6 Do you have a Master's in Library and Information Science or another ALA-accredited graduate degree?

$\square \quad$ Yes (1)

$\square \quad$ No (2) 
Q7 Please indicate if you have a degree(s) in a science discipline. Please check all that apply:

\begin{tabular}{|c|c|c|c|}
\hline & $\begin{array}{l}\text { Bachelor's } \\
\text { Degree (1) }\end{array}$ & $\begin{array}{c}\text { Master's } \\
\text { Degree (2) }\end{array}$ & $\begin{array}{c}\text { Doctoral } \\
\text { Degree (3) }\end{array}$ \\
\hline \multicolumn{4}{|c|}{ I have a degree in a nonscience discipline(s) (20) } \\
\hline \multicolumn{4}{|c|}{ Agriculture (1) } \\
\hline \multicolumn{4}{|l|}{ Astronomy (2) } \\
\hline \multicolumn{4}{|l|}{ Biology/Life Sciences (3) } \\
\hline \multicolumn{4}{|l|}{ Chemistry/Biochemistry (4) } \\
\hline \multicolumn{4}{|l|}{ Computer Science (5) } \\
\hline \multicolumn{4}{|l|}{ Earth Science/Geology (6) } \\
\hline \multicolumn{4}{|l|}{ Environmental Sciences (7) } \\
\hline \multicolumn{4}{|l|}{ Engineering (8) } \\
\hline \multicolumn{4}{|l|}{ Food Science/Nutrition (9) } \\
\hline \multicolumn{4}{|l|}{ Health Sciences (10) } \\
\hline \multicolumn{4}{|l|}{ Marine Science (11) } \\
\hline \multicolumn{4}{|l|}{ Mathematics (12) } \\
\hline \multicolumn{4}{|l|}{ Medicine (13) } \\
\hline \multicolumn{4}{|l|}{ Neuroscience (14) } \\
\hline \multicolumn{4}{|l|}{ Nursing (15) } \\
\hline \multicolumn{4}{|l|}{ Physics (16) } \\
\hline \multicolumn{4}{|l|}{ Psychology (17) } \\
\hline \multicolumn{4}{|l|}{ Statistics (18) } \\
\hline Other science degree (19) & & & \\
\hline
\end{tabular}

Q8 When you began your current position, which of the following did you have? Please check as many as applicable.

$\square \quad$ Science or subject-related degree(s) (1)

$\square \quad$ Science or subject-related experience outside of libraries (5)

$\square \quad$ Library experience in subject area(s) (2)

$\square \quad$ No science or subject-related degree or experience (3)

Q9 What subject areas do you currently cover? (check all that apply)

$\square \quad$ Agriculture (1)

$\square \quad$ Astronomy (2)

$\square \quad$ Biology/Life Sciences (3)

$\square \quad$ Chemistry/Biochemistry (4)

$\square \quad$ Computer Science (5)

$\square \quad$ Earth Sciences/Geology (6)

$\square \quad$ Environmental Sciences (7)

$\square \quad$ Engineering (8)

$\square \quad$ Food Science/Nutrition (9)

$\square \quad$ Health Sciences (10)

$\square \quad$ Marine Science (11) 
$\square \quad$ Mathematics (12)

$\square \quad$ Medicine (13)

$\square \quad$ Neuroscience (14)

$\square \quad$ Nursing (15)

$\square \quad$ Physics (16)

$\square \quad$ Psychology (17)

$\square \quad$ Statistics (18)

$\square \quad$ Other, including nonscience subjects (19)

Q10 Have you assumed new liaison responsibilities for additional departments (adding on to those you already had) in the past 5 years?

$\square \quad$ Yes $(1)$

$\square \quad$ No $(2)$

Skip to: Q13 if Have you assumed new liaison responsibilities for additional departments (adding on to those you... $=$ No

Q11 If yes, are those disciplines in the sciences, or outside of the sciences (or if applicable, both science and nonscience)?

$\square$ Science (1)

$\square \quad$ Nonscience (2)

$\square$ Both (3)

Q12 What was the reason for your additional liaison responsibilities? Select as many as apply.

- Reduced number of librarians due to layoffs (1)

- Reduced number of librarians due to retirements (2)

- Reduced number of librarians due to departure for another position (9)

$\square \quad$ Closure of branch library(ies) (3)

Temporary/interim assignment (4)

- Redistribution of librarians for budgetary reasons (5)

- New disciplinary department or research area(s) created at institution (6)

$\quad$ New area(s) of support to be provided by the library (7)

$\square \quad$ Other (please list) (8)

Q13 Do you have other functional responsibilities in addition to those as a science liaison (for example, scholarly communication, undergraduate experience)? Please check all that apply.

Data Management Services (1)

Emerging Technologies (2)

$\square \quad$ First Year/Undergraduate Experience (3)

Instruction/Instructional Design Librarian (4)

$\square \quad$ Scholarly Communication/Open Access (5)

$\square \quad$ User Experience (6)

$\square \quad$ Website Services (7)

$\square \quad$ Other $(8)$ 
Q14 What is the highest degree granted by your institution?

口 Doctorate (1)

Master's (2)

Bachelor's (3)

․ Associate's (4)

Q15 What is the size of your total student population?

$\square$ Fewer than $1,000(1)$

$\square \quad 1,000-2,999(2)$

3,000-9,999(3)

ㅁ $10,000-19,999(4)$

20,000-29,999 (6)

$30,000+(5)$

Q16 Is your institution public or private?

$\square$ Public (1)

$\square \quad$ Private (2)

$\square$ Other (3)

Q17 Do librarians at your institution have faculty status?

$\square \quad$ No (1)

$\square \quad$ Yes, with tenure (2)

Yes, without tenure (3)

- Yes, both with tenure and without tenure (4)

$\square$ Other (5)

Q18 How many dedicated science libraries does your institution have? For this survey, do not count medical or health sciences only libraries (that is, those that do not serve other science disciplines).

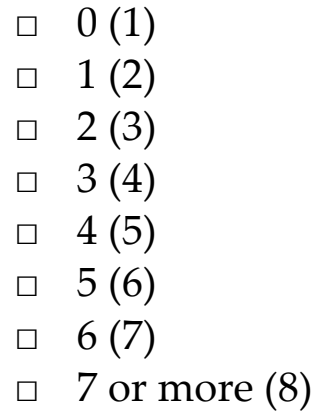

Q19 Have any of the science libraries been closed or merged with other libraries in the past 5 years?

$\square \quad$ Yes $(1)$

$\square \quad \mathrm{No}(2)$

Skip to: Q21 if Have any of the science libraries been closed or merged with other libraries in the past 5 years? $=$ No 
Q20 If you answered yes to the previous question, please say which one(s) merged or closed, and why.

Q21 How many science liaison librarians does your institution have? Do not count Health Science or Medical Librarians if they don't also liaise with another science department(s).

For this survey, a science liaison librarian is a librarian with liaison responsibilities to one or more science departments, with subject knowledge in these disciplines.

$\square \quad 0$ science subject librarians (1)

$\square \quad 1(2)$

$\square \quad 2-4(3)$

$\square \quad 5-7(4)$

8-10 (5)

$\square \quad 11-13(6)$

$\square \quad 14$ or more $(7)$

Skip to: End of Survey if How many science liaison librarians does your institution have? For this survey, a science liaison $l=0$ science subject librarians

Q22 Has the number of science librarians at your institution increased or decreased since you've been there? Please enter the number of years you've been at your current institution.

$\square \quad$ Number of science librarians increased. Please enter the number of years you've been at your institution. (1)

$\square \quad$ Number of science librarians stayed the same. Please enter the number of years you've been at your institution. (2)

$\square \quad$ Number of science librarians decreased. Please enter the number of years you've been at your institution. (3)

Q23 For each task, indicate the percent of time you spend that is related to science. For example, when doing reference, what percentage of questions that you answer are science related? Enter numbers only.

Collection development (1)

Reference including virtual (2)

Information literacy/library instruction (3)

Outreach to departments (4)

Outreach to campus units or community groups (5)

Committee work (6)

Outside service to professional organizations (7)

Scholarly communication (8)

Research data management services (9)

Research/writing for publication (10)

Other, please enter: (11)

Q24 Thinking about the future, predict the percent of time you will spend on each task that will be related to science. For example, when doing reference, what percentage of questions 
do you think will be science related? Enter numbers only.

Collection development (1)

Reference including virtual (2)

Information literacy/library instruction (3)

Outreach to departments (4)

Outreach to campus units or community groups (5)

Committee work (6)

Outside service to professional organizations (7)

Scholarly communication (8)

Research data management services (9)

Research/writing for publication (10)

Other, please enter: (11)

Q25 Rate the necessity of science subject knowledge on the performance of your job duties.

\begin{tabular}{|c|c|c|c|c|c|c|}
\hline & $\begin{array}{l}\text { No subject } \\
\text { knowledge } \\
\text { is needed } \\
\text { to perform } \\
\text { this task } \\
\text { (1) }\end{array}$ & $\begin{array}{l}\text { Subject } \\
\text { knowledge } \\
\text { is helpful but } \\
\text { not essential } \\
\text { to perform } \\
\text { this task (2) } \\
\end{array}$ & $\begin{array}{l}\text { Some } \\
\text { subject } \\
\text { knowledge } \\
\text { is needed to } \\
\text { perform this } \\
\text { task (3) }\end{array}$ & $\begin{array}{l}\text { Subject } \\
\text { knowledge } \\
\text { is important } \\
\text { to the } \\
\text { performance } \\
\text { of this task (4) }\end{array}$ & $\begin{array}{l}\text { Subject } \\
\text { knowledge } \\
\text { is essential } \\
\text { to the } \\
\text { performance } \\
\text { of this task (5) }\end{array}$ & $\begin{array}{l}\text { Not } \\
\text { applicable } \\
\text { to me (6) }\end{array}$ \\
\hline \multicolumn{7}{|l|}{$\begin{array}{l}\text { Collection } \\
\text { development (1) }\end{array}$} \\
\hline \multicolumn{7}{|l|}{$\begin{array}{l}\text { Reference } \\
\text { including virtual (2) }\end{array}$} \\
\hline \multicolumn{7}{|l|}{$\begin{array}{l}\text { Information } \\
\text { literacy/library } \\
\text { instruction (3) }\end{array}$} \\
\hline \multicolumn{7}{|l|}{$\begin{array}{l}\text { Outreach } \\
\text { to liaison } \\
\text { departments (4) }\end{array}$} \\
\hline \multicolumn{7}{|l|}{$\begin{array}{l}\text { Outreach to other } \\
\text { campus units } \\
\text { or community } \\
\text { groups (5) }\end{array}$} \\
\hline \multicolumn{7}{|l|}{$\begin{array}{l}\text { Committee work } \\
(6)\end{array}$} \\
\hline \multicolumn{7}{|l|}{$\begin{array}{l}\text { Service to } \\
\text { professional } \\
\text { organizations (7) }\end{array}$} \\
\hline \multicolumn{7}{|l|}{$\begin{array}{l}\text { Scholarly } \\
\text { communication } \\
(8)\end{array}$} \\
\hline $\begin{array}{l}\text { Research data } \\
\text { management } \\
\text { services (9) }\end{array}$ & & & & & & \\
\hline
\end{tabular}




\begin{tabular}{|l|l|l|l|l|l|l|}
\hline $\begin{array}{l}\text { Research/writing } \\
\text { for publication } \\
(10)\end{array}$ & & & & & & \\
\hline Other (11) & & & & & & \\
\hline
\end{tabular}

Q26 Please indicate which of these activities you predict will increase, decrease, or stay the same in the future, regardless of whether or not you do them now.

\begin{tabular}{|l|l|l|l|}
\hline & $\begin{array}{c}\text { Will increase in } \\
\text { the future (1) }\end{array}$ & $\begin{array}{c}\text { Will stay the } \\
\text { same (2) }\end{array}$ & $\begin{array}{c}\text { Will decrease in } \\
\text { the future (3) }\end{array}$ \\
\hline Collection development (1) & & & \\
\hline Reference including virtual (2) & & & \\
\hline Information literacy/library instruction (3) & & & \\
\hline Outreach to liaison departments (4) & & & \\
\hline Outreach to other campus units or community groups (5) & & & \\
\hline Committee work (6) & & & \\
\hline Service to professional organizations (7) & & & \\
\hline Scholarly communication (8) & & & \\
\hline Research data management services (9) & & & \\
\hline Research/writing for publication (10) & & & \\
\hline Other (11) & & & \\
\hline
\end{tabular}

Q27 Please indicate your perception of the value placed on a science degree or previous science experience by:

\begin{tabular}{|l|l|l|l|l|l|}
\hline & $\begin{array}{c}\text { Not valued } \\
\text { at all (1) }\end{array}$ & $\begin{array}{c}\text { Not very } \\
\text { valued (2) }\end{array}$ & $\begin{array}{c}\text { Neutral } \\
\text { (3) }\end{array}$ & $\begin{array}{c}\text { Somewhat } \\
\text { valued (4) }\end{array}$ & $\begin{array}{c}\text { Highly } \\
\text { valued (5) }\end{array}$ \\
\hline Your library administration (1) & & & & & \\
\hline Your nonscience librarian colleagues (2) & & & & & \\
\hline Your science librarian colleagues (3) & & & & & \\
\hline $\begin{array}{l}\text { The faculty in the science departments you } \\
\text { serve (4) }\end{array}$ & & & & & \\
\hline $\begin{array}{l}\text { The students in the science departments } \\
\text { you serve (5) }\end{array}$ & & & & & \\
\hline $\begin{array}{l}\text { Faculty and students in nonscience } \\
\text { departments (6) }\end{array}$ & & & & & \\
\hline
\end{tabular}

Q28 Do you think that a science degree, or previous experience in or related to your subject areas, contributes to your ability to perform your subject job responsibilities? Please select one answer.

$\square \quad$ I don't have a science degree or previous experience, but I think having one or both would help me perform my subject job responsibilities. (3)

$\square \quad$ I don't have a science degree or previous experience, and I don't think having either one would help me perform my subject job responsibilities. (4)

$\square$ My science degree or previous experience contributes significantly to my ability to 
perform my subject job responsibilities. (1)

$\square \quad$ My science degree or previous experience contributes somewhat to my ability to perform my subject job responsibilities. (2)

$\square$ My science degree or previous experience does not significantly contribute to my ability to perform my subject job responsibilities. (5)

Q29 Thinking about the future, do you think it will be necessary or desirable for academic science librarians to have a degree or related experience in a science discipline?

$\square \quad$ A science degree or experience will be necessary. (1)

$\square \quad$ A science degree or experience will be desirable but not necessary. (2)

$\square \quad$ A science degree or experience won't be necessary. (3)

Q30 Thinking about the future, do you think the practice of liaison librarianship in the sciences will continue?

$\square$ Science librarians will continue to liaise with science departments. (1)

$\square$ Most librarians will liaise with both science and nonscience departments. (2)

$\square$ Liaison librarianship as a practice will be discontinued. (4)

Q31 What do you think will be the future of science librarianship?

Q32 This is the last question! Is there anything else you would like to tell us?

\section{Notes}

1. Richard H. Dillon, "The Phantom of the Library: The Creative Subject Specialist," in Library Lectures, ed. Caroline Wire (Baton Rouge: Louisiana State University Library, 1971), 100.

2. Tim Collins, "The Current Budget Environment and Its Impact on Libraries, Publishers and Vendors," Journal of Library Administration 52, no. 1 (2012): 18-35, https://doi.org/10.1080/01930826.2012.630643.

3. Charles I. Guarria and Zhonghong Wang, "The Economic Crisis and Its Effect on Libraries," New Library World 112, no. 5/6 (2011): 199-214, https://doi.org/10.1108/03074801111136248; Charles B. Lowry, "Themes within the ARL Strategic Plan 20102012," Research Library Issues: A Bimonthly Report from ARL, CNI, and SPARC, no. 268 (February 2010): 1-9, available online at https://files.eric.ed.gov/fulltext/ED511063.pdf [accessed 9 October 2019].

4. Fred J. Hay, "The Subject Specialist in the Academic Library: A Review Article," Journal of Academic Librarianship 16, no. 1 (1990): 11-17.

5. Gail F. Latta, ARL SPEC Kit 189: Liaison Services in ARL Libraries (Chicago, IL: Association of Research Libraries: SPEC Kit 189, 1992), available online at https://babel.hathitrust.org/cgi/pt?id=mdp.39015029544189;vie $\mathrm{w}=1 \mathrm{up} ; \mathrm{seq}=1$ [accessed 15 January 2019].

6. T.F. Currier, "Subject Specialist," College \& Research Libraries 2 (December 1940): 14-21.

7. Anna Marie Johnson, "Connections, Conversations, and Visibility: How the Work of Academic Reference and Liaison Librarians Is Evolving," Reference \& User Services Quarterly 58, no. 2 (2019): 91-102, https:// doi.org/10.5860/rusq.58.2.6929; Paul Metz, "Quantifying the Workload of Subject Bibliographers in Collection Development," Journal of Academic Librarianship 17, no. 5 (1991): 284-87; Gary W. White, "Academic Subject Specialist Positions in the United States: A Content Analysis of Announcements from 1990 through 1998," Journal of Academic Librarianship 25, no. 5 (1999): 372-82, https://doi.org/10.1016/S0099-1333(99)80056-1.

8. Debbi A. Smith and Victor T. Oliva, “Becoming a Renaissance Reference Librarian in Academe: Attitudes toward Generalist and Subject Specific Reference and Related Profession Development," Reference Services Review 38, no. 1 (2010): 125-51, https://doi.org/10.1108/00907321011020770.

9. Dan Hazen, "Twilight of the Gods? Bibliographers in the Electronic Age," Library Trends 48, no. 4 (2000): 821-41, available online at www.ideals.illinois.edu/bitstream/handle/2142/8320/librarytrendsv48i41_opt.pdf?s [accessed 4 December 2018]. 
10. Kristine K. Stacy-Bates et al., "Competencies for Bibliographers," Reference \& User Services Quarterly 42, no. 3 (Spring 2003): 235-41, available online at https://lib.dr.iastate.edu/cgi/viewcontent.cgi?article=1033\&conte $\mathrm{xt}=$ refinst_pubs [accessed 18 December 2019].

11. T. Glynn and C. Wu, "New Roles and Opportunities for Academic Library Liaisons: A Survey and Recommendations," Reference Services Review 31, no. 2 (2003): 122-28, https://doi.org/10.1108/00907320310476594; John Rodwell and Linden Fairbairn. "Dangerous Liaisons? Defining the Faculty Liaison Librarian Service Model, Its Effectiveness and Sustainability," Library Management 29, no. 1/2, (2008): 116-24, https://doi. org/10.1108/01435120810844694.

12. Ricardo Andrade and Raik Zaghloul, "Restructuring Liaison Librarian Teams at the University of Arizona Libraries, 2007-2009," New Library World 111, no. 7/8 (2010): 273-86, https://doi.org/10.1108/03074801011059911; Clarence Gorchels, "Making Subject Specialists Available for Service," College and Research Libraries 16, no. 4 (1955): 347-49; Metz, "Quantifying the Workload of Subject Bibliographers in Collection Development," 284.

13. Julie Hallmark, "Education for the Successful Geoscience Information Specialist," Science \& Technology Libraries 17, no. 2 (1998): 81-91.

14. C.L. Renfro and L.J.O. Critz, “How to Be a Subject Specialist When You Aren't: Engineering Librarianship for the Non-Engineer," Proceedings of the ASEE Annual Conference \& Exposition (June 2018), available online at https://peer.asee.org/30584.pdf [accessed 18 December 2019].

15. C. Hooper-Lane, "Spotlight on the Subject Knowledge of Chemistry Librarians: Results of a Survey," Issues in Science and Technology Librarianship 23 (Summer, 1999), https://doi.org/10.5062/F4W9574V.

16. Pali U. Kuruppu, "Recruitment of Science and Technology Librarians: A Review," Science E Technology Libraries 27, no. 1/2 (2006): 11-39, https://doi.org/10.1300/J122v27n01_03; Nedelina Tchangalova, "Jumping onto the Bandwagon: New Librarians Navigating the Science/Technology Librarianship," Electronic Journal of Academic and Special Librarianship 10, no. 3 (2009), available online at https://drum.lib.umd.edu/bitstream/handle/1903/14750/ Tchangalova_2009.pdf?sequence=1\&isAllowed=y [accessed 16 December 2019]; Mark Winston, "Academic Science and Engineering Librarians: A Research Study of Demographics, Educational Backgrounds, and Professional Activities," Science \& Technology Libraries 19, no. 2 (2001): 3-24, https://www.tandfonline.com/doi/pdf/10.1300/ J122v19n02_02.

17. Latta, ARL SPEC Kit 189, 4.

18. Susan Logue et al., ARL SPEC Kit 301: Liaison Services (Chicago, IL: Association of Research Libraries: SPEC Kit 301, 2007), available online at http://publications.arl.org/Liaison-Services-SPEC-Kit-301/, [accessed 16 December 2019].

19. Rebecca K. Miller and Lauren Pressley, ARL SPEC Kit 349: Evolution of Library Liaisons (Chicago, IL: Association of Research Libraries: SPEC Kit 349, 2015), available online at http://publications.arl.org/EvolutionLibrary-Liaisons-SPEC-Kit-349/ [accessed 16 December 2019].

20. Joy Kirchner, "Scholarly Communications: Planning for the Integration of Liaison Librarian Roles," Research Library Issues, no. 265 (August 2009): 22-28, available online at https://publications.arl.org/rli265/23 [accessed 16 December 2019].

21. T. Gabridge, “The Last Mile: Liaison Roles in Curating Science and Engineering

Research Data," Research Library Issues, no. 265 (August 2009): 15-21, available online at https://publications. arl.org/rli265/16 [accessed 16 December 2019].

22. Christie Peters and Anita Riley Dryden, "Assessing the Academic Library's Role in Campus-Wide Research Data Management: A First Step at the University of Houston," Science E Technology Libraries 30, no. 4 (2011): 387-403, https://doi.org/10.1080/0194262X.2011.626340.

23. Karen Williams, "A Framework for Articulating New Library Roles," Research Library Issues, no. 265 (August 2009): 3-8, https://publications.arl.org/rli265/4.

24. Barbara Rockenbach, "What Are We Trying to Build?" Research Library Issues, no. 294 (2018): 3-7, https:// doi.org/10.29242/rli.294.

25. Sonja L. McAbee and John-Bauer Graham, "Expectations, Realities, and Perceptions of Subject Specialist Librarians' Duties in Medium-Sized Academic Libraries," Journal of Academic Librarianship 31, no. 1 (2005): 19-28, https://doi.org/10.1016/j.acalib.2004.09.006.

26. Neil Nero and Anne Langley, "Subject Liaisons in Academic Libraries: An Open Access Data Set from 2015," portal: Libraries and the Academy 17, no. 1 (2017): 5-15, https://doi.org/10.1353/pla.2017.0001.

27. Jacquelyn Burkell, "The Dilemma of Survey Nonresponse," Library and Information Science Research 25, no. 3 (2003): 239-63, https://doi.org/10.1016/S0740-8188(03)00029-X.

28. John J. Meier, “Are Today's Science and Technology Librarians Being Overtasked? An Analysis of Job Responsibilities in Recent Advertisements on the ALA JobLIST Web Site," Science E Technology Libraries 29, no. 1/2 (March 9, 2010), 165-75, https://doi.org/10.1080/01942620903579443. 